\title{
LOCAL DEVELOPMENT STRATEGIES WITHOUT STRATEGIC THINKING: LOST IN BETWEEN POLITICIANS' GAMES, ADMINISTRATIONS' RIGIDITY AND PLANNER'S DEPRESSION
}

\section{A B S T R A C T}

A large number of different strategies at the central, regional and local level have been done in the last decade in Serbia. Studies on their quality show that quite a number of strategic documents meet the standards in their form, but in terms of the content, they do not have a clear strategy and strategic projects, they overlap and are poorly intercoordinated. The paper indentifies and discusses the stages and steps in the strategic planning process, that are crucial for formulating long-term sustainable development solutions for a specific territory and the improvement of its citizens' lives. Its main thesis is that the local strategies lack the strategic thinking, i. e. that the solutions are not based on its products. Attitudes about the causes of the lack of the strategic in the strategies are illustrated with a specific example: the planning process and the content of the Development strategy of the City of Pančevo. 


\section{INTRODUCTION}

A large number of different development strategies at the central, regional and local level have been done in the last decade in Serbia. The motives that underlie their preparation are twofold. On the one hand, they are the consequence of striving for harmonization with the legislation and the European Union practice in the public policy area. On the other hand, they are the means to overcome weakness of formal planning system to provide answers to complex developmental problems in a dynamic environment.

About 91 sectoral and 14 intersectoral strategies on the national level were produced and were active according to data from 2014 ${ }^{1}$. Analysis carried out in 2010 within the project "Support to strengthening the coordination of active policitics in the Serbian Government" , was concluded with the finding that only $50 \%$ of the reviewed strategies should be kept and updated, i. e. that there are big overlaps among them and that a large number of them is obsolete.

Today there is almost no municipality or city in Serbia which has not at least one strategic document, whether it is a comprehensive or a sectoral strategy. At the local level, according to the Standing Conference of Towns and Municipalities' $(\mathrm{SCTM})^{3}$ database of the local strategic documents, there are 867 registered planning processes ${ }^{4}$ in municipalities and cities in Serbia. This means that cities and municipalities in Serbia, on average, have adopted 5.2 strategic/ action plans. Twenty-seven percent of the total number of strategies and action plans are the comprehensive local strategies, $20 \%$ are the strategies in the field of the social protection, and then the strategies of economic development, local environmental action plans, action plans for improving the status of refugees and displaced persons, local action plans for children and local plans for young people follow ${ }^{5}$. The local strategic documents mass development was started after extention of local self-governments' original jurisdiction in $2002^{6}$. Special encouraging factors have been and still are the EU Instruments for Pre-Accession Assistance (IPA) to the candidate countries. The access to these funds is conditioned by the existence of: (1) the strategic document, (2) the mechanisms for the establishment of the cooperation between national institutions and donors, (3) the mechanisms for establishing connections between priorities and funding, and (4) the existence of mechanisms for monitoring the implementation of strategies and projects, as well as evaluating of their performance. This conditioned access has launched an avalanche of making development strategies at different levels and characters. Thus, for example, in order to align with the 2014-2020 financial framework of the European Union, the Provincial Secretariat for Local Self-Government of AP Vojvodina financed comprehensive strategies development in 15 towns in Vojvodina within this time range. 
According to the research on strategic planning in Serbia, despite the large number of strategic documents, the system of planning and public policies coordination in Serbia is not sufficiently developed. At the conference "Do We Plan the Future of Serbia" held in 2014, it was concluded that "the majority of strategic documents do not have clear strategy, that they significantly overlap, that no attention is paid to the strategic importance of the projects, that they do not include action plans nor have a clear link with the budget planning, as well as a clear monitoring system of their implementation and evaluation".

Thus, despite the practice and experience of nearly two decades, the support of numerous international expert teams, published manuals and guides, as well as a growing number of people (in all of the three sectors) who had the opportunity to participate in the process of making a strategic document, our development strategies generally represent "the dead letters".

The main objective of this paper is the identification and discussion of the issues and stages in the planning process, which can be crucial for formulating strategic and long-term sustainable development solutions for specific territories and improvement of the lives of its citizens. The main stance is that the local development strategies lack strategic thinking, i. e. that the solutions are not based on its findings. Attitudes about the possible causes of the lack of the strategic in the strategic documents are illustrated with the planning process and the content of the Development Strategy of the City of Pančevo. Findings are generated from a dual perspective: the "internal" - from the position of the consultant for strategic planning methodology who had the opportunity to influence the process and the content of the strategy, and "external" - from the position of a researcher who could monitor and analyze the possibilities of application of collaborative planning model developed for the previous theoretical research ${ }^{8}$.

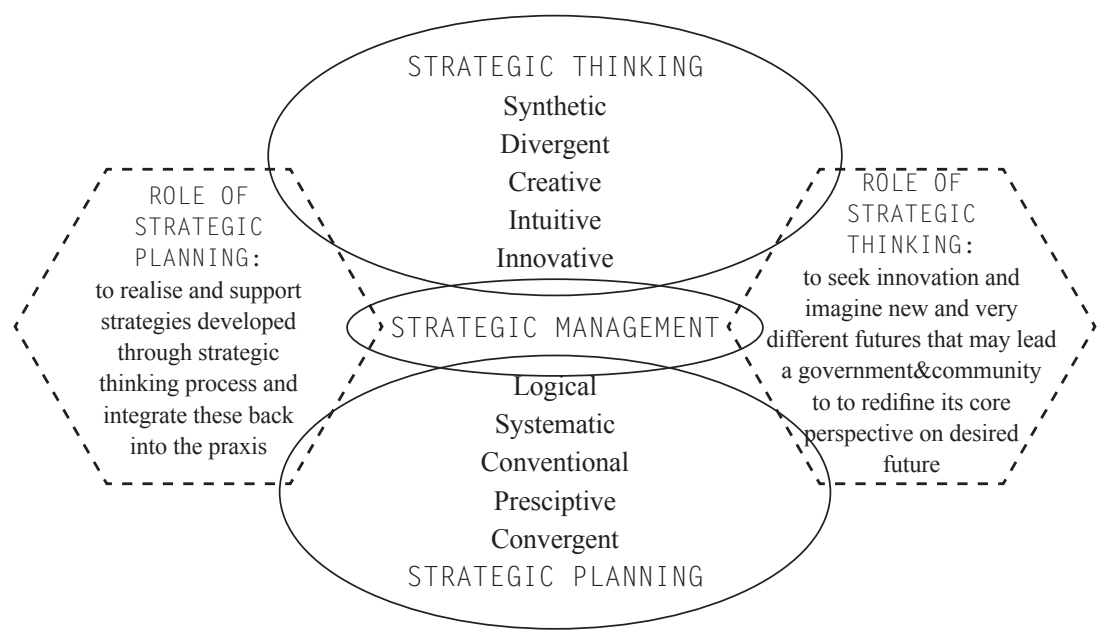




\section{(COLLABORATIVE) STRATEGIC PLANNING AND STRATEGIC THINKING}

Planning is a complex process of preparation, formulation and implementation of the decisions regarding the future. Decisions are the response to the existing problems and opportunities on the one hand, and the idea of a desired future on the other. Strategic planning is the public authorities` activity that coordinates the development of the territory at various levels, regulates and controls different processes within the same. Products of the strategic planning are the strategies and their action plans which define in detail the activities, timelines, indicators, required resources, legislative and institutional framework for their implementation in order to achieve defined objectives. The role of strategic planning is to "formulate and realize the strategies based on a process of strategic thinking"9 (Figure 1).

The design of the planning process should enable strategic thinking, and the products of strategic planning should be based on it. Strategic thinking and planning are "different, but interrelated and complementary processes" which are essential for effective strategic management, i. e. the formulation and realization of sustainable strategies ${ }^{10}$. Strategic thinking aims to provide meaningful information, creation of the ideas, the search for innovation and different futures that could lead to redefining of perception and the way we think about things or the way we perform some tasks.

Strategic thinking has five main characteristics: it has a systemic perspectives, it is intent-focused, involves thinking in time, it is hypothesis-driven and it is intelligently opportunistic"11. According to Liedktka ${ }^{12}$, a strategic thinker "could be regarded as the one who learns, rather than the one who knows". Strategic thinking process cannot be easily described, systematized and rationalized, and thus made easier for learning and aquiring. That makes it a critical part of the planning process. Possible implications of the characteristics of strategic thinking to the design of the strategic planning process concern primarily methods and techniques (Figure 2), as well as their positions and the method of their implementation in the planning process.

\begin{tabular}{ll}
\hline ELEMENTS OF STRATEGIC THINKING & RELEVANT STRATEGY CONCEPTS \& TECHNIQUES \\
\hline \multirow{2}{*}{ Systems Perspective } & Stakeholder mapping \\
& Value System analysis \\
& Future Search Conference \\
\hline Intent Focused & Story writing \\
\hline \multirow{2}{*}{ Thinking in Time } & Scenario Building \\
& Gap analysis \\
& Use of analogies \\
\hline \multirow{2}{*}{ Hypothesis Driven } & What if .. if then \\
& Knows, Unknows, Presumed \\
& Aleksander's Question \\
\hline \multirow{2}{*}{ Intelligent Opportunism } & Share and Compare \\
& Simulation Techniques \\
\hline
\end{tabular}

Figure 2. The implications of the characteristics of strategic thinking on the choice of methods and techniques of strategic planning. Source: Liedtka, J. (1998). Strategyc Thinking: Can it be Taught?. Long Range Planning, vol 31, no 1, pp. 126 
So, the planning of the strategic actions should be preceded by creative thinking of possible actions that could be taken. Imagination of different futures should be followed by formulation of the desirable options which have to be rationally evaluated and compared. The one that is in accordance with the assessment of the available resources should be chosen. However, in the context of complex developmental problems that cities face today, planning rationality is not enough. The process of searching for solutions and their realization are becoming more complex because different stakeholders have to be involved.

Thus, when it comes to the strategic planning of community development, the ability of the individuals (political leaders or experts) to generate different ideas is not enough. This means that it is necessary to develop a collaborative planning models and methods that enable the integration of technical, social and natural sciences on the one hand, and on the other hand, intensive and active participation and cooperation of a wide range of actors, which often involve conflicting perspectives ${ }^{13}$. Strategic thinking skills require a combination with the skills of improved communication and cooperation while providing the conditions for the realization of collaborative rationality of the all involved in the planning process ${ }^{14}$. For successful collaborative process, it is not enough to collect the people and tell them to cooperate, but it is necessary to fulfill the conditions for reaching the collaborative rationality ${ }^{15}$. According to the Innes\&Booher's theory of collaborative rationality (DIAD), key requirements are that the participants: (1) Represent the full diversity of interests, (2) Have interrelated dependence, that is that they cannot achieve their own interests independently. In such situations, everyone has something that someone else needs. (3) Are engaged in face-to-face dialogue that respects Habermas conversational conditions: (a) The process of deliberation is provided, (b) All the participants are fully informed, (c) All the participants are able to present their own views, (d) All the participants are listened to, (e) There is support in order to establish the legitimacy and reliability of the spoken, and (f) it is necessary to strive for a consensus.

Innes\&Booher ${ }^{16}$ consider that it is very important to stress that collaborative processes are not always collaboratively rational. According to them, collaborative rationality represents a new form of planning and management and is an essential alternative to the traditional linear model that primarily relies on expert knowledge. Collaborative processes which are collaboratively rational result in specific socially valuable/useful results. Products of such processes can be very diverse in form. Collaborative processes are adaptive and they constantly evolve: they adapt to the opportunities and challenges of shifting context that is specific and unique. The key argument is that it provides the change of the system due to the changing of attitudes, relationships, and capabilities of the participants. 
The collaborative planning model is not derived from theoretical findings on the characteristics of the desired planning model and development management. It is the consequence of the failure of the rational model to cope with the increasingly complex problems in more dynamic, more unstable and more unpredictable environment/context. The theorists, the practitioners and the authorities embraced the collaborative planning, each in their own way. Their arguments and motives are of philosophical, practical or political-ideological origin. They all agree that it is more democratic way of decision-making which in a better way reflects the everyday reality of modern life. On the other hand, it proved to be a more effective form of governance. The Authorities act in a complex context, in which the power to implement and take action and responsibility for them are divided between several different types of actors.

The implications of understanding that the strategic thinking and collaborative approach are prerequisites of successful strategic planning are:

- The focus is on the ability for strategic thinking of those who are responsible for strategy development (especially leaders), and the involvment of all those (in the community) who have them also,

- The role of the planner, in addition to the expert one, is to be the catalyst that encourages the strategic thinking of others involved in the process,

- The design of the planning process is that the skills of strategic thinking can be encouraged, practiced, realized and developed within many people.

\section{STRATEGIC PLANNING IN SERBIA}

There are several researches on strategic planning in Serbia ${ }^{17}$ and their findings have similar conclusions: the strategies in Serbia are often mutually conflicted, their goals are unrealistically set, the way in which the priorities are set out is vague. According to analysis conducted within the project "Support to strengthening coordination of active policies in the Government of Serbia", less than $30 \%$ of documents had clearly stated strategy, over $25 \%$ significantly overlapped, about $25 \%$ had clear plans of action, while less than $10 \%$ contained any kind of performance assessment. Similarly, it is proposed that less than $50 \%$ of the examined strategies should be retained and updated. In the Report of the European Commission on Serbia's progress for $2013^{18}$, it is stated that "the lack of coherent sectoral strategies and strategic investment plans leads to a poor preparation of projects" ${ }^{\prime 19}$. The SCTM $^{20}$ study analyzed 40 SCTM strategic documents of various kinds from 20 municipalities and concluded that "the insufficiently clear and workable national strategies are major challenge in defining local strategies" ${ }^{21}$, that most of the strategies and projects are not aligned with the real size of the budget of the municipalities"22, as well as the 
budget is prepared without relying on a planning document, that municipalities often do not act following the plans and deadlines for the execution of the strategic documents, and that the priorities are changed by the individuals' will.

The greatest number of strategic documents were supported (initiated) by the international partners. This assistance, in almost all cases, concerned the financial aid package, conditioned by planning methodology and measures for raising the capacities of local administration employees. Comprehensive strategies, including the strategies for local sustainable development are mainly financed from EU development programs, such as MIR 2, PRO, SMEs and NO EXCHANGE 2. Development strategies of social welfare services are mainly supported by the EU through the Social Innovation Fund and DFID and the Government of Norway, with the support and participation of the Ministry of Labour and Social Policy. Most of the local environmental action plans were supported by the Regional Centre for Environmental Protection from Budapest, and plans for management of municipal waste by GTZ. Local action plans for children were supported by UNICEF, local plans for youth by Ministry of Youth and Sports, and action plans dealing with the problems of refugees and displaced persons with the help of international donors were supported by the Commissariat for Refugees of the Republic of Serbia.

As a part of the package for capacity building of local administration employees, in Serbia were published several manuals and guidelines for the strategic planning of different quality. Only a few high-quality manuals do not represent a schematic set of practical guidelines, but also explain the reasons because of which an integrated approach, a methodological process and the importance of compliance with local resources are recommended. It very often resulted in literal downloading of the recommended methodological procedures which is not adapted to the local development context and the specifics of the conditions in which the planning process took place. It is one of the disputable themes when talking about collaborative processes, and Guijt and $\mathrm{Shah}^{23}$ call that the paradox of participation. Standardization can be considered the opposite of what is the essence of collaborative processes - a departure from the "schematic planning to find more flexible methodologies and those more oriented to the very content". Collaborative processes should have a high level of adaptability, that is the possibility of various planning processes. According to the traditional understanding, the planning process and its products schould be placed in the "formal arenas", in which the behavior and actions of people are defined by procedures and positions ${ }^{24}$. Unlike traditional forms, collaborative processes are highly effective only if they have a high level of voluntary contribution, informality and flexibility. In recent years, the prevailing understanding is that the capacities of agencies and agents are much higher than those defined by formally procedures ${ }^{25}$, i. e. that only informal relationships and networks play 
significant roles in the creation and adoption of such procedures. The importance of understanding "uniqueness of each individual practice" is highlighted, compared to the "the reading of individual cases through the generalized lens of procedural rules or manuals of best practices"26.

DEVOLPEMENT STRATEGY OF THE CITY OF PANČEVO 2014-2020

City of Pančevo Development Strategy 2014-202027 resulted from the revision of the previous Development Strategy of Pančevo Municipality 2007-2025 produced during the period 2004 to 2007 . The audit was launched for two reasons: the local government considered that solutions offered by the existing strategy were not in line with the changes in the global and local economic context. The second reason was an initiative of the Provincial Secretariat for Interregional Cooperation and Local Self-Government (which funded the revision of the existing Strategy) to prepare the strategic documents in all the municipalities in AP Vojvodina in order to make them compatible with a new EU financial framework. Pančevo's government estimated that due to "good practices in implementing local sectoral strategies and greater number of action plans", the job of creating strategy can be done relying on their own human resources. Therefore, they made a decision in October 2013 to establish the Review Team responsible for Strategy development (hereinafter referred to as "Team"). The team had 19 members and consisted from the mayor, deputy mayor, 4 members of the City Council, 9 employees in the City Administration, 1 representative of the public sector of Construction Direction of Pančevo, a representative of the Regional Development Agency RDA Banat Zrenjanin and 1 hired consultant for strategic planning methodology ${ }^{28}$. None member of the Team was released from his usual tasks (even Team Coordinator), and all of them, for their efforts, were further, but very modestly paid. All members of the Team are locals.

The Team was interested in facilitating citizens' participation in the planning process as follows:

- By informing about the process and achieved results through local media and social networks,

- By creating the focus groups for key development topics, and

- By formulating various questionnaires at different stages of the process that people were able to complete on-line or in a "traditional" way in key locations in the City.

The Team singled out five key issues (economy, agriculture, environmental protection, spatial and urban planning and social development) of importance for the development of the Strategy, and for each of them a focus group was formed, composed of actors that are assumed (by the Team members) to be able 
to contribute to the success of the Strategy (for any reason). Each group had its own coordinator, who was also a member of the Team.

During the phase of the analysis of the territory, in addition to the collecting and processing of standard sectoral data, 13 meetings with focus groups were held. The focus group meetings involved a total of 279 experts, private entrepreneurs, public figures, representatives of NGOs. In the above mentioned areas key problems, causes of the problems and ideas about possible solutions were identified.

Additionally, three surveys were formulated and made available to on the website of the City of Pančevo for two months. Those surveys were also available in hard copy in the local communities' offices, the City Service Center, City Hall and the Cultural Centre:

- General survey in which citizens declared the kind of a city they want to live in, vision of the City of Pančevo in 2020, the most significant development potentials / the biggest weaknesses of the City of Pančevo, and they also gave suggestions regarding the development of the City. 748 citizens responded ti the survey.

- Survey on environmental protection which covered the most important issues on the environmental situation in the City and suggestions for improving the situation, about which 223 citizens declared.

- Survey for businesses that is delivered to the addresses of 130 commercial organizations and included questions about their business, difficulties, development plans and proposals for the improvement of the business environment in the city of Pančevo. Through this survey, the data from 30 industrial organizations were collected.

Besides that, the Team placed a call to the citizens to send the project ideas for the development of the City via the website and social networks. The data and ideas from all surveys were taken into consideration in the Strategy formulation process.

After the City analyses were done, the Team prepared the strategic objectives and the methodology for establishment of priorities, and based on that, the City Council defined the 11 strategic priorities. The Team prepared a first Draft of the Strategy in april 2014 and made it available to all interested in on the website of the City of Pančevo. The Team organized 11 public meetings which were attended by 183 interested experts, representatives of institutions, business organizations of CSOs and citizens. During the public hearing, 50 suggestions and comments on the preliminary draft arrived in writing through specially prepared form that was available both on the City website and in 


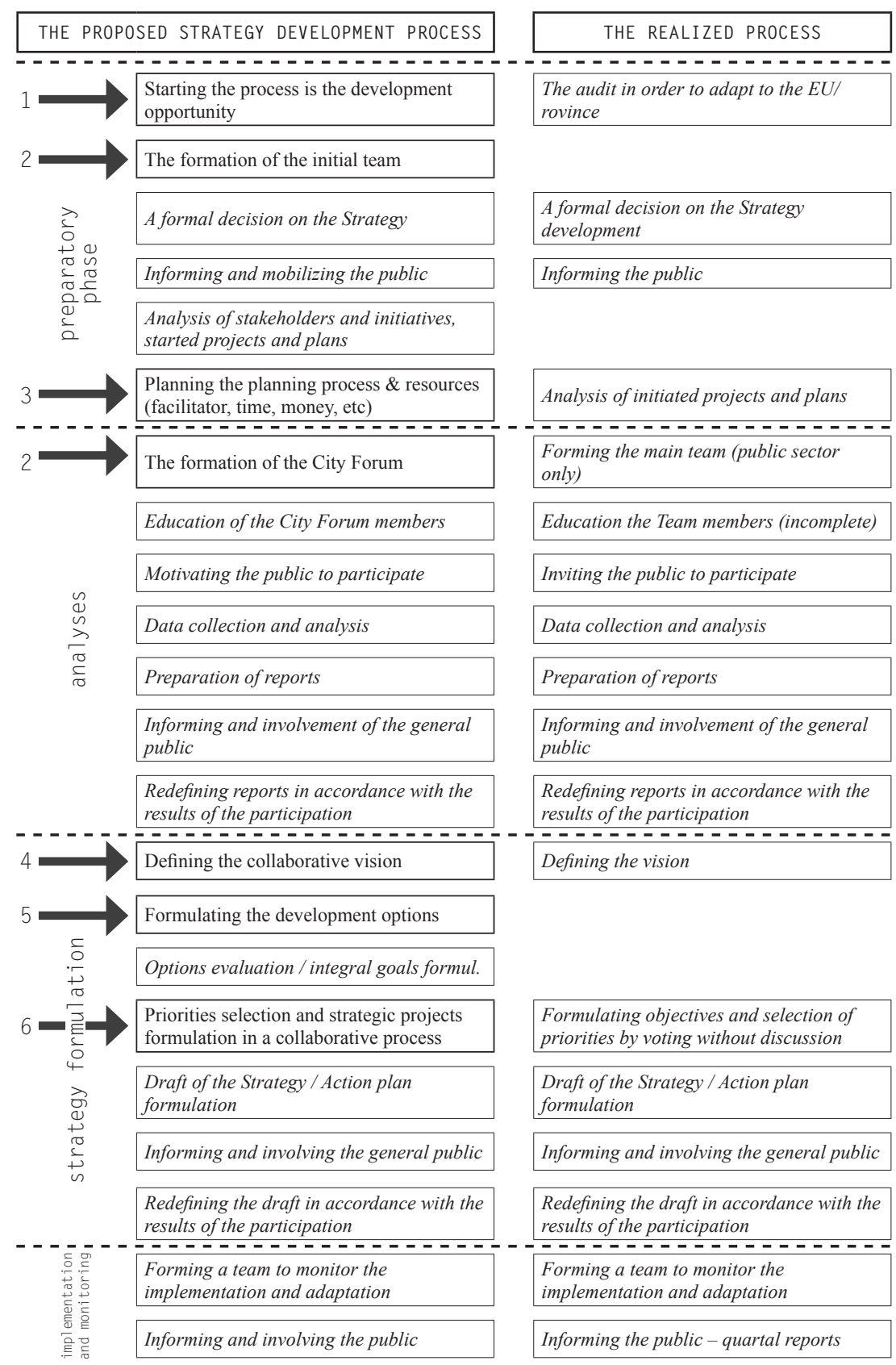


the municipality service center. Remarks, comments and suggestions were processed and partly included in the text, on what basis was prepared the final Draft of the Strategy for the Development of the City of Pančevo 2014-2020. It was submitted to the City Council for consideration and determination of the proposal to the Assembly of the City of Pančevo. The Strategy was adopted on 24 October 2014.

At the outset of the process, the consultant proposed to the Team members that the planning process schould be designed in accordance with the principles of collaborative-communicative planning, as well as that the citizens schould be informed and consulted about the entire process and its results. According to that, the design and the methodology of the planning process were proposed. Figure 3 shows the comparison of the proposed process and the one carried out in the Strategy development process, indicating the key areas for strategic thinking. Those positions will be especially discussed further in the paper.

\section{The Strategy development process is an opportunity for the community}

The strategy development process can be understood as the opportunity to review and rethink of the working "as usual" patterns, generate innovative solutions, establish new partnerships and identify new resources for their implementation. The Administration of the City of Pančevo, unfortunately, despite the secured financial and institutional support, has not used this opportunity adequately. The time span of seven years (2014-2007) had to be interpreted only as the first of several in a series of documents that would support the development of the City in accordance with a long-term vision. However, the Team believed that the basic purpose of the Strategy was to be an instrument for resolving the current problems, but not an instrument of searching for and tracing to the desired future.

The Team is the key to the successful process and

the City Forum is the key to the dialogue about the City

The ability of members of the Strategy Team to collaborate and question the existing and create new answers to distinct development issues and challenges are prerequisites for strategic thinking in the planning process. It is therefore proposed that, in addition to the opening of the process for active, continuous and constructive participation of the citizens, the Tim itself shoul be opened for continuous collaboration and to joined work with the representatives of major institutions, groups of citizens and businesses and to form the City Forum (Figure 4). 


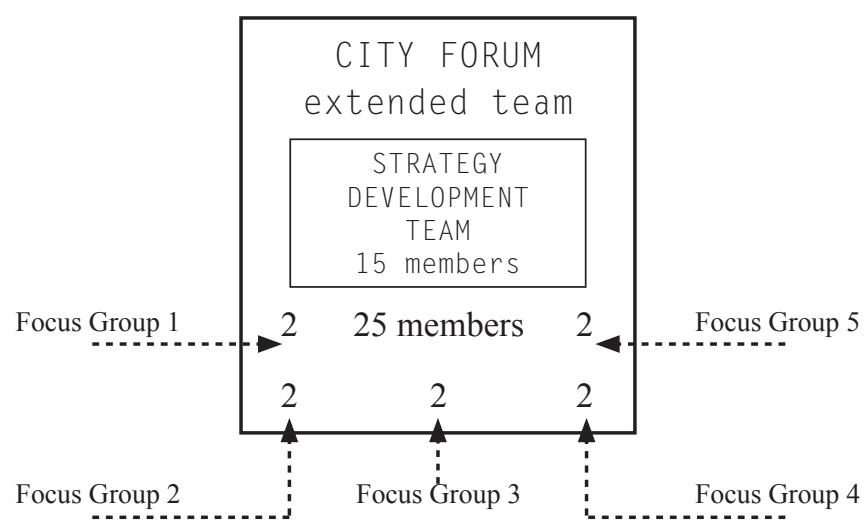

\footnotetext{
Figure 4. The proposed model of the formation of the City Forum: After initial stakeholder analysis, the Team should be joined with another 10 members (two from each focus group). When selecting new Team members, the representation of diverse interests, worthiness to work in groupe and interest in working on a project like this should be taken into account
}

Therefore, special attention must be given to the foundation of the initial Team and the recommendation is that the City leaders, such as the mayor, do that in cooperation with the facilitator with whom the understanding of the purpose of planning was achieved before. The initial Team agrees the mode of work, provides the resources (people, space, equipment, finance, media, etc.), and also elects new members of the City Forum, who should represent the interested/ cultural diversity of the City. The proposed organization of work, responsibilities and the relationship between the City Forum, the Team, focus groups and the general public are shown in Figure 5.

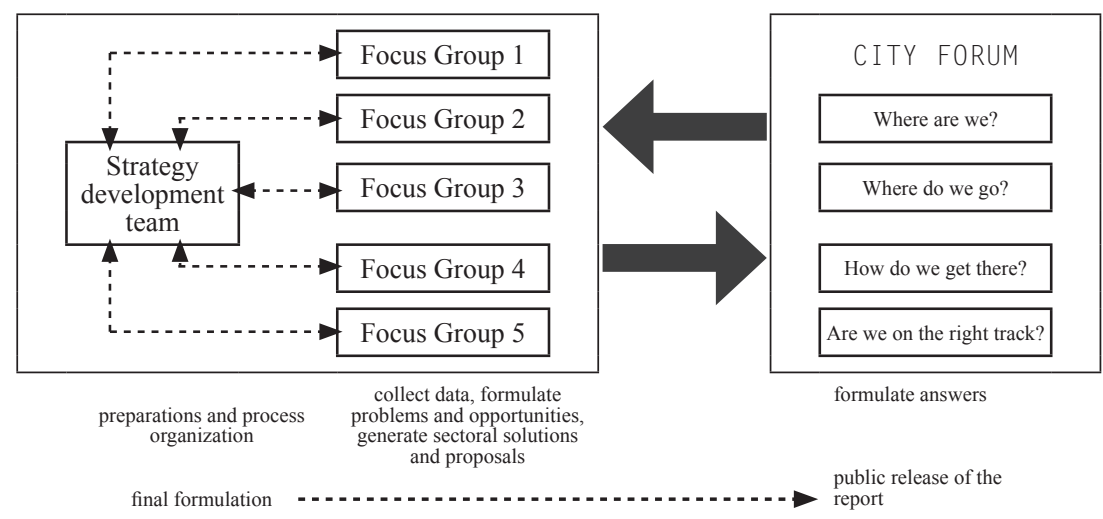

Figure 5. The proposed organization of work: duties and the relationship between the City Forum, the Team, focus groups and the general public. The proposal was not explicitly denied, but was not implemented by the Team either 
The formation of the City Forum as a multisectoral and multidisciplinary team could contribute to establishing a dialogue on strategic and long-term development of the City. The idea of forming the City Forum was never openly rejected, it was not materialized until the end of the process. The greatest resistence of the Team members to the idea was a consequence of understanding that opening and cooperation with those outside the public sector would be a confession of impotence and incompetence of the administration to realize the process to an end. Moreover, rivalry and struggle for positions, scores, and political points were very much present, not only between the different parties, but also within them as well.

\section{The planning of the process and providing the resources}

Key factors for the success of collaborative strategic planning process are careful planning and designing of the process itself. According to Forester ${ }^{29}$, the communication in planning is of political nature and it is determined by the structure of the planning process: "When a local organization or entrepreneur gets the information may be just as important as the information obtained. What planners do not say can be just as important as what they say. Planners shape not only a document or an information, but also citizens' access to the information, their understanding and interpretation of such information, as well as their ability to participate effectively in the political processes that affect their lives. The structure of the planning process reflects the form of communication, which affects the organization of the community, citizen participation, and autonomous action of a responsible citizen".

Collaborative planning requires an appropriate environment in institutional and organizational terms. In this sense, Innes \& Booher ${ }^{30}$ believe that for its realization is very important the existence of a leader and dedicated staff. The reallization of an authentic dialogue requires good preparation, education and training of the participants and managers of the process. There are principles and good practices examples that the realization of an authentic dialogue can be relied upon, but it is crucial that every situation is different and that it requires different modalities, i. e. that every dialogue is authentic!! The quality of the outcome depends very much on the ability of the participants to communicate productively. An authentic dialogue is not just verbal communication and it is not expected to be spontaneous in occurrence within large groups. It is necessary to provide adequate conditions in which the interview takes place, as well as to train people to accept new ways of thinking and speech. Without these conditions, it is very difficult to ensure retention in the process, i. e. meet a key condition for achieving collaborative rationality - diversity of interests represented. 
The process of developing the Strategy of Pančevo can be considered the planning process, which was open for public participation, but was not collaborative, even within the Team. The Team did not have a facilitator, but that role was occasionally assumed by the coordinator of the strategy, who, at the same time, was in a very unenviable position given that it was on a lower position in the hierarchy in relation to a large number of Team members. The authority of the facilitator could be provided by political leaders, but, in this case, it did not happen. The document was created in a standard procedure which involves the synthesis of partial/sectoral contributions, with only the Team coordinator and a couple of his associates familiar with the whole proposal. In addition, no other basic working conditions were provided, such as separate premises and equipment, access to finance and adequate working time. Great quality of the document in the sense of the word tidiness and literacy is therefore a consequence of the enthusiasm, dedication and knowledge of the coordinator of the Strategy.

\section{The vision makes sense only if it is created in a collaborative process}

One of the key opportunities for the promotion and realization of strategic thinking is a collaborative visioning - formulating of shared/integral vision of community development/respective territories. Visioning process usually represents an important, often turning stage in the process, in which, due to the generation of common ideas on the future development, forms a stronger sense of belonging to the Team and the responsibility for the development of local community. After visioning, the perceptions of the participants about the relationship between individual and collective/public interest often changes, that has then been perceived as a basis/condition for the better of individuals/ vested interests/groups. Therefore, the key value of collaborative visioning is not in the product as it is in the process in which it occurs. Without a chance to settle in a face-to-face dialogue, it is only more or less pretty optimistic sentence that does not have a deeper meaning and has no foundation in reality because it did not create additional value - realization of understanding and mutual inspiration of the Team members.

In the process of formulating the Strategy of Pančevo, the vision was formulated by several Team members on the basis of the findings in the phase of analysis of the situation and initiatives with so-called "patchwork technique" and not in the joined visioning process, which is considered a necessary prerequisite for a change of sectoral and individual in an integral and joined understanding of the development of the City. The vision was then presented and adopted without discussion at a meeting of the Team (the Team meetings were never attended by all members, and the mayor and some members of the City Council were only at the first meeting). 
Development options are a prerequisite of different way of working and thinking

Additionaly, the formulation of the vision in a collaborative process is the recommendation that in the collaborative process should be formulated various development options, which can be based on different value orientations and priorities. The reason for that is that, due to the multiplicity of interests represented, it is very difficult to formulate an optimal development solution at the very beginning of the planning process. Formulation of a variant is used to enable access to a wider offer for the purpose of choosing the best course of the development in certain areas. This procedure involves identifying a group of actors with different interests, but also with different roles, positions and power in the society. The function of the said variant approach to planning, in recent years, particularly promotes the use of the scenario method. Different scenarios review different development options which can often be opposed to the views currently applicable not only in the region but also in the framework of the planning Team. Besides they can contribute to the reduction of manipulation in the use of knowledge and better understanding of the preferences of actors, they can make a significant contribution to achieving compromise and consensus to conflict resolution. Overall, the scenario analysis provides a broader and more creative thinking about the future, i. e. strategic thinking. Planning options must be evaluated from different viewpoints, to demonstrate both the good and bad sides of proposals, that is to keep in mind all the benefits and costs. With this, managing (only) by intuition or the interests of some powerful interest groups can be avoided. The options must "pass" the assessment and verification on various aspects of evaluation by the members of the City of Forum and working groups, and the general public to the public.

In the process of drafting the Strategy of Pančevo, the development options are not formulated. Methodology consultant proposed organization of a two-day workshop at which the extended Tim would generate the options, evaluate and implement the choice. The proposal was not explicitly denied, nor the reasons were disclosed, but the development of the Strategy took place in a standard way via translating sectoral goals into the sets of the activities.

\section{Development projects in the form of narratives}

In the continuation of the process, after the formulation of the strategic objectives, the Team started their operationalization by defining a set of activities and their attributes in a standard format: time of realization, responsible and accountable for the implementation, budget, etc. Activities largely represented the current maintenance and standard set of investments that are purported in a 
city even without the existence of the Strategy. This is proof that the Strategy was created as the need to "solve the problem" rather than as a desire to "use the opportunities and new ideas."

To the Team was proposed to organize an extensive list of aforementioned activities and thus reconsider the formulation of strategic projects that could be discussed and that could be the presented in the form of a narrative. Such an approach would allow better understanding and integration and rationalization of the activities that would be undertaken. Without such groupings into development projects, it is impossible to achieve the integral development of a territory, but the activities remain sectoral activities whose meaning and position in the system are difficult to understand and monitor outside the narrow circle of people in whose jurisdiction it is located.

\section{CONCLUSION}

Although in Serbia there is no institutionalized system of quality assessment, monitoring and evaluation of the effects of the implementation of strategies, programs and projects, on the basis of a few sporadic researches, as well as on the basis of the low level of their implementation, it can be concluded that a large number of strategic documents complies with standards in their form, but that, in terms of content, those are without a clear strategy and strategic projects, that they overlap and are poorly intercoordinated.

We believe that the problem is primarily caused by a lack of leadership of local governments which understand the benefit of and is able to build an effective partnership between all "stakeholders" (private sector, civil society, local government officials and politicians). Strategies that should change the reality, not only in respect to the present problems, but in line with a strong common vision, presuppose the existence of administration/politicians capable of strategic thinking, and the affirmation of the same with the other whose activities are relevant to the development of the community. In contrast, our public policy and public services have become arenas and products that capture short-term political points, and in which political parties fight for the rating and not only with each other, but also their management staff within them.

On the other hand, there are professional services and professional planners who, pressed by numerous regulations and procedures, pressures, and concerns regarding the retention of the workplace, left the "reins" of the planning process to the political and financial interests and gave up on the idea that reality can be interpreted, and also changed in a creative way. Thus the strategical 
planning takes place within the standardized template for programs produced by the schemes of the planning process, according to the toolkits and manuals developed by the various international and domestic organizations and experts. Although in this way the practice of discipline is facilitated, it also "represents a potential danger for each the same, because in such proceedings inevitably happens the removal of practical methods from the starting point on which they should be based." In this way, the possible is "reckless application of the same without a deeper understanding of their meaning and the philosophy on which they are based", i. e. the routine and template approach. It is therefore very important to understand that the strategic planning process must be distinguished on the basis of the development of the context in which they formed, and not on the basis of methodological procedures, methods and techniques that dominate in professional practice. It is important not to ask in relation to these recommended procedures "with the same awe, ignorance and fear as poor rural priest toward the mighty Latin cadences of Thomistic theology"31. We believe that the methodological procedures must be continuously critically examine in order to avoid "following a methodology as rituals that become purpose for themselves" 32 , and contributes to the transformation of the same in accordance with your values and commitments.

Although in the local development planning in recent years there is an increasing trend of involving the public, this practice is not uniform and is mostly predominantly formal, because it is more about fulfilling the form, and less a result of understanding the utility. Politicians and professionals of public services are generally uninterested in cooperation with civil and business sector and include them "out of inertia, as this is done in other municipalities/ cities, and because it is perceived as a kind of obligation, and not because they believe that they can, with their competencies, information from the field and expertise, contribute to the better results of that process". The study on civil sector participation in the development of local strategies examined ${ }^{33}$ CSOs statements that "where there is a sincere desire to cooperate, it primarily comes from the educated and sensible local officials, who in the process recognize the interest of the local community through the involvement of civil society organizations, while political structures generally have not developed sufficient awareness about the importance of the civil sector can play in the process of strategic planning, i. e. that the "rigidity of the municipal/city administration and inadequate human resources" the ones who contribute to "activities related to the development of strategic documents are carried out with very little enthusiasm and without sufficient knowledge". From the questionnaires intended for businesses in Pančevo, we state the paragraphs which are confirmed by the views of NGOs: "The work of these institutions is directed "inwards", not "outwards". Overall, institutions behave as if they were an aim 
for themselves, not as they are made in order to solve problems in their field of work". It also states that the obstacles to generating new and innovative solutions in the cooperation process are"sluggishness, incompetent administration and lack of understanding of the functioning of the economy". An interesting feature is their perception of the reasons to refuse the cooperation: "I'm trying to figure out why this is so, and I find no other response but the fact that we are dealing with vain, immature and very terrestrial world. If only there is a little understanding of what could one of us get, I think that they would'n let us home until they get everything we can give them. However, those of their ignorance, hotshots and paranoia, see us as a potential threat, not a help. ... on every meeting we beg them to get us involved and they explain that it is exactly what they do ... it ends with endless tirades of the people unaware of their own incompetences. Every initiative for creative conversation is destroyed. ... We can tell them about social responsibility, convince them that our interest in the City was the primary motive for participation in the development of the Strategy. They do not trust us.“

In the conclusion we can emphasize that providing the conditions for generation of collaborative strategic thinking on cross-sectoral/interdisciplinary workshops of the expanded city team for formulating a common vision, elaboration of different development scenarios, their analysis and comparison, and a selection of a set of development programs, projects and activities, depends on understanding local political leaders that they represent income for the city, as well as knowledge of administration and planners to implement the process. There will always be the representatives of civil society and private sector stakeholders to live in a healthy and successful cities and to join the job competently and actively.

NOTES

O. Milić, Unapređenje sistema strateškog i operativnog planiranja u Republici Srbiji (Beograd: Evropski pokret u Srbiji, 2014), 7.

Commissioned by the General Secretariat of the Government of the Republic of Serbia

The Standing Conference of Towns and Municipalities (SCTM). the database is updated continuously. The first survey was conducted in 2007 in all municipalities and cities in Serbia. A unique database with information about all municipalities' / cities' strategic documents was established: the time period, the area of strategy, institutions engaged in formulation or implementation at the local level, as well as requirements for building capacities.

The adopted plans, plans in the planning process and plans that have not yet been adopted by local parliaments

V. Kopanja i dr., Analiza procesa planiranja u gradovima i opštinama u Republici Srbiji (Beograd: SKGO, 2013), 14.

Vlada Republike Srbije. Zakon o lokalnoj samoupravi (Beograd: Službeni glasnik RS, br. 9/2002 i 33/2004), članovi 54-56 
The conference was held on 05.05.2014. It was organized by the Research Forum of the European Movement in Serbia on the occasion of presentation of the report entitled "Improving the system of strategic and operational planning in Serbia" written by Ognjen Miric. The recommendations in this report "should help the Government of the Republic of Serbia to improve the decisionmaking as well as relevant ministries and in order to achieve results with a greater effect in the circumstances of limited financial resources". For more see the http:/www.mc.rs/planiramo-libuducnost-srbije.4.html? eventId=9369 (10.10.2015)

The author got a PhD from the Faculty of Architecture, University of Belgrade in 2013 with the theme "Improving the model of citizen participation in urban planning of Serbia in accordance with the communicative-collaborative paradigm."

F. Graetz, "Strategic Thinking versus Strategic Planning: Towards Understanding the Complementarities," Management Decision, Vol. 40 Iss: 5 (2002), 457. Ibid, 461.

J. Liedktka, "Strategic Thinking-Can It Be Taught?," Long Range Planning, Vol 31, No 1 (1998), 120

Ibid, 124.

S. Doyle i M. Batty. Vitrual Regeneration (University College London: Centre for Advanced Spatial Analysis, 1998)

J. Innes i D. Booher. Planning with Complexity: An Introduction to Collaborative Rationality for Public Policy (Routledge, 2010).

Ibid, 10.

Ibid, 35.

The paper used the following studies: Kancelarija za saradnju sa civilnim društvom (2012); O. Milić (2014) i V. Kopanja i dr. (2013)

Evropska Komisija, Izveštaj o napretku Srbije za 2013. godinu (Beograd, 2014)

Ibid, 47.

V. Kopanja i dr., Analiza procesa planiranja u gradovima i opštinama u Republici Srbiji (Beograd: SKGO, 2013),

Ibid, 40

Ibid, 22

F. Fisher, F. et al. Building Bridges between local governments and citizens through Participatory Planning: Part I - Concepts (FPDL, UN HABITAT Training and Capacity Building Branch, Local Government Initiative of the Open Society Institute. 2001), 19.

P. Healey. "In Search of the "Strategic" in Spatial Strategy Making," Planning Theory \& Practice, Vol. 10, No. 4 (2009), 444.

P. Healy. "Collaborative planning in perspective," Planning Theory, vol 2 (2) (2003): 101-123.

P. Healey. "In Search of the "Strategic" in Spatial Strategy Making," Planning Theory \& Practice, Vol. 10, No. 4 (2009), 445.

Of importance to this paper is that its author was the consultant in the planning process.

Forester, 1980:275

See endnote no. 26

B. Bognar. "Stvaralački pristup znanosti,” Metodički ogledi. Vol 15(1) (2008), 13

Ibid, 13

Vlada Republike Srbije, Kancelarija za saradnju sa civilnim društvom. Učešće civilnog sektora u dosadašnjem strateškom planiranju na lokalnom nivou u Srbiji: Nalazi i preporuke (Beograd, 2012), 31 
Bognar, B. “Stvaralački pristup znanosti.” Metodički ogledi. Vol 15(1) (2008): 11-30.

Doyle, S. i M. Batty. "Vitrual Regeneration." University College London: Centre for Advanced Spatial Analysis, 1998. Available at http://www.casa.ucl.ac.uk (accessed, 10.10.2015)

Evropska Komisija. Izveštaj o napretku Srbije za 2013. godinu. Beograd, 2014. Available at http:// europa.rs/upload/2014/izvestaj_ek 2013.pdf (accessed, 12.09.2015)

Fisher, F. et al. Building Bridges between local governments and citizens through Participatory Planning: Part I - Concepts. FPDL, UN HABITAT Training and Capacity Building Branch, Local Government Initiative of the Open Society Institute. 2001.

Forester, J. "Critical Theory and Planning Practice." Journal of the American Planning Association, Volume 46, Issue 3 (1980): 275-286.

Generalni sekretarijat Vlade. Podrška osnaživanju koordinacije aktivne politike u Vladi Srbije. Beograd, 2010 : 4-20.

Graetz, F. "Strategic Thinking versus Strategic Planning: Towards Understanding the Complementarities.” Management Decision, Vol. 40 Iss: 5 (2002): 456 - 462.

Healy, P. "Collaborative planning in perspective." Planning Theory, vol 2 (2) (2003): 101123. Available at http://sunsite.berkeley.edu/CurrentCites/2000/cc00.11.9.html (accessed, 10.10.2015)

Healey, P. "In Search of the "Strategic" in Spatial Strategy Making." Planning Theory \& Practice, Vol. 10, No. 4 (2009): 439-457.

Innes, J. i D. Booher. Planning with Complexity: An Introduction to Collaborative Rationality for Public Policy. Routledge, 2010.

Kopanja, V., I. Teodorović i Z. Njegovan. Analiza procesa planiranja u gradovima i opštinama u Republici Srbiji Beograd. Beograd: SKGO, 2013. Available at http://www.skgo.org/ publications/download/465 (accessed, 10.10.2015)

Liedktka, J. "Strategic Thinking-Can It Be Taught?” Long Range Planning. Vol 31, No 1 (1998): 120-129.

Milić, O. Unapređenje sistema strateškog i operativnog planiranja u Republici Srbiji. Beograd: Evropski pokret u Srbiji, 2014.

Milovanović Rodić, Danijela. "Redefinisanje modela učešća građana u urbanističkom planiranju Srbije u skladu sa komunikativno-kolabortaivnom paradigmom.” Doktorska disertacija, Arhitektonski fakultet Univerziteta u Beogradu, 2013.

Skupština grada Pančevo. Strategija razvoja grada Pančeva. Pančevo, 2014. Available at http:// www.pancevo.rs/_STRATEGIJA_RAZVOJA_GRADA_PANCEVA_2014_2020_-327-1-3430 (accessed, 10.10.2015.)

Vlada Republike Srbije, Kancelarija za saradnju sa civilnim društvom. Učešće civilnog sektora u dosadašnjem strateškom planiranju na lokalnom nivou u Srbiji: Nalazi i preporuke. Beograd, 2012. Available at http://www.parlament.org.rs/res/Izve\%C5\%A1taj-CSF-final.pdf (accessed, 10.10.2015.)

Vlada Republike Srbije. Zakon o lokalnoj samoupravi. Beograd: Službeni glasnik RS, br. 9/2002 i 33/2004. Available at http://demo.paragraf.rs/combined/Old/t/t2004 03/t03 0118.htm (accessed, 10.10.2015) 
ekonomske krize u Grčkoj, na infrastrukturne mreže je dramatično uticalo fragmentisano odlučivanje između različitih nivoa planiranja i aktera. Studija slučaja predstavljena u radu, u užem smislu, se odnosi na poboljšanje železničkog sistema u Patrasu, u Grčkoj, a u širem smislu, studija slučaja razjašnjava neformalnu proceduru planiranja (tzv. test-planiranje) poboljšanja železničkog saobraćaja. Ideja primene takvog postupka u Patrasu se pojavila pre dve decenije kao rezultat iskazanih interesa različitih aktera vezanih za integraciju železničkog saobraćaja u urbano tkivo. Međutim, i dalje je evidentno odsustvo efikasne saradnje između inicijatora ovog postupka i lokalnih vlasti. Metodologija istraživanja u radu je razvijena u nekoliko koraka. Prvo, biće predstavljen širi problem i potencijal razvoja infrastrukture. Drugo, ukratko će biti predstavljen proces test-planiranja. Na kraju, biće pomenut značaj lokalne samouprave u takvom postupku saradnje i slučaj lokalnih aktera u Patrasu u različitim fazama procesa test-planiranja, kao kritički okvir postojećeg stanja i pouka za buduće korake.

KLJUČNE REČI: ŽELEZNIČKA INFRASTRUKTURA, URBANI RAZVOJ, SARADNJA, NEFORMALNE PROCEDURE ZA PLANIRANJE, GRČKA

LOKALNE RAZVOJNE STRATEGIJE BEZ STRATEŠKOG RAZMIŠLJANJA:

IZGUBLJENE IZMEĐU IGRE POLITIČARA, RIGIDNOSTI UPRAVE I

DEPRESIJE PLANERA

\section{Danijela Milovanović Rodić}

U poslednjoj deceniji u Srbiji je izrađen veliki broj strategija različitog karaktera na centralnom, regionalnom i lokalnom nivou. Istraživanja njihovog kvaliteta pokazuju da veliki broj strateških dokumenata svojom formom zadovoljava standarde, ali da su po pitanju sadržaja bez jasne strategije i strateških projekata, da se preklapaju i da su slabo međusobno koordinisane.

U radu su identifikovane i diskutovane faze i koraci u procesu strateškog planiranja od ključnog značaja za formulisanje strateških i na dug rok održivih rešenja za razvoj određene teritorije i unapređenje života njenih građana. Osnovna teza je da u lokalnim strategijama razvoja nedostaje strateško razmišljanje, odnosno da rešenja nisu bazirana na njegovim produktima. Stavovi o uzocima odsustva strateškog u strategijama su ilustrovani konkretnim primerom - procesom izrade i sadržajem Strategije razvoja Grada Pančeva.

KLJUČNE REČI: STRATEŠKO PLANIRANJE, STRATEŠKO MIŠLJENJE, KOLABORATIVNO PLANIRANJE, PROCES PLANIRANJA

\section{TERITORIJALNA ORGANIZACIJA REPUBLIKE SRBIJE - MOGUĆNOSTI ZA REFORME \\ Bogoljub Milosavljević, Jelena Jerinić}

Trenutna teritorijalna organizacija Srbije praktično je postavljena tokom šezdesetih godina 20. veka. Velike demografske i ekonomske promene nisu se odrazile na promene u propisima o teritorijalnoj organizaciji. Takva teritorijalna organizacija osnova je jednostepenog i gotovo potpuno monotipskog sistema lokalne samouprave. Pošto daju detaljan prikaz propisa o teritorijalnoj organizaciji i lokalnoj samoupravi u prethodna dva veka, autori analiziraju sadašnji sistem i skiciraju moguće pravce reforme teritorijalne organizacije. Te predloge treba posmatrati u svetlu napora ka većoj decentralizaciji i uspostavljanju višestepene i/ili politipske lokalne samouprave.

KLJUČNE REČI: TERITORIJALNA ORGANIZACIJA, LOKALNA SAMOUPRAVA, OPŠTINE, GRADOVI, DECENTRALIZACIJA 